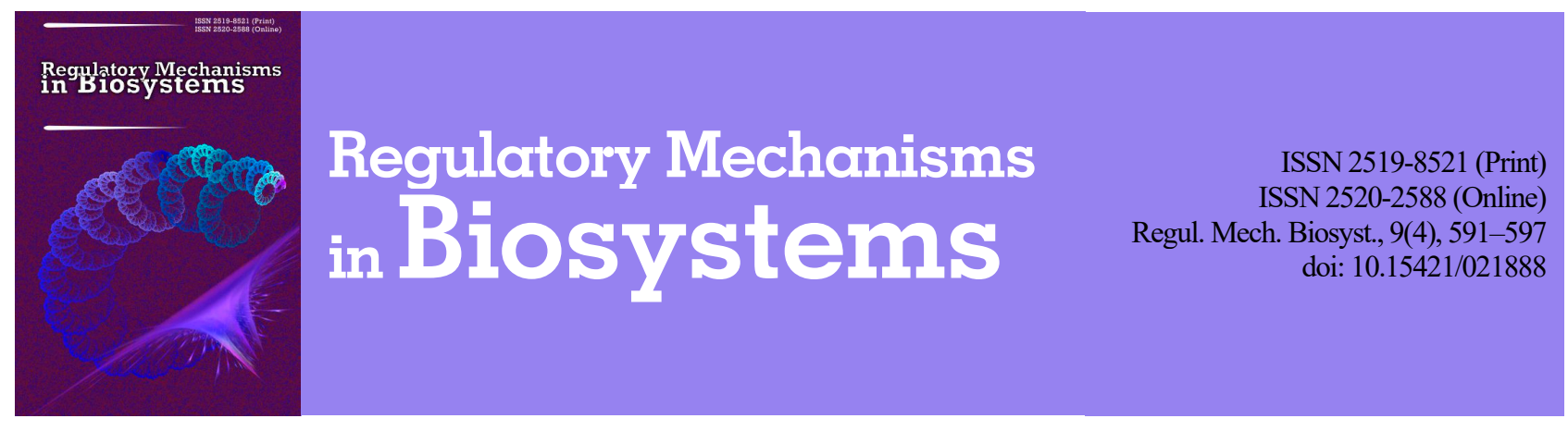

\title{
Combined effect of glyphosphate, saccharin and sodium benzoate on rats
}

\author{
M. A. Lieshchova*, N. M. Tishkina*, A. A. Bohomaz*, P. M. Gavrilin*, V. V. Brygadyrenko*,** \\ *Dnipro State Agrarian and Economic University, Dnipro, Ukraine \\ **Oles Honchar Dnipro National University, Dnipro, Ukraine
}

Article info

Received 14.10.2018

Received in revised form 11.11.2018

Accepted 16.11.2018

Dnipro State Agrarian and Economic University, Serhii Efremov st., 25 , Dnipro, 49600, Ukraine. Tel. $+38-056-268-54-17$. E-mail:

lieshchova.m.o@dsau.dp.ua

Oles Honchar Dnipro National University, Gagarin av., 72, Dnipro, 49010, Ukraine. Tel.: +38-050-93-90-788 E-mail:brigad@ua.fm

\author{
Lieshchova, M. A., Tishkina, N. M., Bohomaz, A. A., Gavrilin, P. M., \& Brygadyrenko, V. V. (2018). Combined effect of \\ glyphosphate, saccharin and sodium benzoate on rats. Regulatory Mechanisms in Biosystems, 9(4), 591-597. \\ doi:10.15421/021888
}

Herbicides and food additives are included in many food products for humans. Non-used products or products beyond their expiry date are deposited in places of utilizatioin of solid municipal wastes, where they can take effects on the organisms of mouse-like rodents. Among the herbicides, glyphosphate takes first place in the world for volume of production, and is the most intensely used in agricultural farming. The discussion about negative impact on the organisms of mammals, especially against the background of using various substances and environmental factors, continues. In this study, we determined the combined effect of glyphosphate and food additives on the organism of laboratory animals, which manifested in changes in body weight, condition and indices of mass of the internal organs and blood parameters. Four groups of laboratory male rats were formed, which over 42 days received: unlimited access to clean water; $1 \%$ aqueous solution of glyphosate; $1 \%$ solution of glyphosphate and $1 \%$ solution sodium benzoate; $1 \%$ solution of glyphosphate with $1 \%$ solution of saccharin. Glyphosphate and glyphosphate with sodium benzoate and saccharin significantly reduced the daily increases in body weight of animals compared to the control group. The studied substances have notable suppressive effect on the immune system and haematopoiesis in general, which is manifested in reduce of relative mass of the thymus and spleen against the background of increase in the amount of lymphocytes in the peripheral blood. The inhibition of haematopoiesis is indicated by decrease in the amount of erythrocytes, neurophils and hemoglobin of blood of animals from the experimental groups. The impact on the digestive system of glyphosphate and food additives is indicated by occurance of the effect of "irritation" of mucous membranes, and, as a result, disorders in absorption followed by the disorder in metabolic processes. A dysbalance occurs in enzymic systems of the organism, which is manifested in distrophic processes, especially in the liver parenchyma, indicated by the activity of blood enzymes (ALT, AST, alkaline phosphatase), total number and ratio of proteins of blood plasma. We determined the impact of glyphosphate and its mixes with benzoate and saccharin on the pancreas, which manifests in severe pancreatitis with steep increase in the level of glucose of blood. The results of the study allow us to state that mixture of glyphosphate and food additives can cause toxic effect in animals and humans, which often contact with herbicides.

Keywords: herbicide; glyphosphate; cholesterol; biochemical parameters of blood; relative mass of the organ

\section{Introduction}

Combination of pollutants in the diet of human and animals can have ill defined effects on the organism. Herbicides and food additives are included in many food products for humans, and unused food products or products beyond their expiry date are deposited in the places of storage and utilization of solid municipal waste. There they become food for synantropic rodents (rats and mice).

Glyphosate, or $\mathrm{N}$-(phosphonomethyl)glycine, $\mathrm{C}_{3} \mathrm{H}_{8} \mathrm{NO}_{5} \mathrm{P}$, is globally one the most widely used non-selective herbicides of systemic effect. Among the herbicides, it takes first place in the world for volume of production, and is the most intensely used in the history of chemicals in agriculture (Benbrook, 2016). Glyphosate is the active substance of many preparations produced under trade names such as "Roundup", "Uragan", "Tornado" and others. In Ukraine, there are registered around 30 such preparations, and their use annually equals 1000-1500 tons, in the USA - 17,000-22,000 tons of this herbicide are used annually (Kuznetsova \& Chmil, 2010; Kniss, 2017). The preparation forms on the basis of glyphosate are different in percentage proportion of the substances they contain. Most often, they contain 1-41\% glyphosate, surfactants and various secondary components, including foaming-preventing substances, colourings, biocides and non-organic ions for stabilizing $\mathrm{pH}$ (Brad- berry et al., 2004). From the chemical perspective, glyphosate is a weak organic acid. In preparation forms glyphosate is converted into saline form (potassium, ethanolamine, dimethylamine, ammonium or isopropylamine), due to which it becomes well-soluble in water and becomes chemically stable.

Glyphosate is widely used on cultivated fields (grain, vegetables, legume, oil-bearing crops, and melons), in gardens, parks and forests, and also in water resources. It is efficient in the areas of non-agrarian purpose against weeds and unwelcome vegetation, open drainage and irrigation systems, drainage canals. Glyphosate has low mobility in soil and is poorly leached. It is considered that the remains of glyphosate from weeds, introduced to the soil do not enter into other plants. In soil, glyphosate has a short half-life into stable metabolites, which depends on the type of soil and its $\mathrm{pH}$ (Yu \& Zhou, 2005; Gardner \& Nelson, 2008). The main route of introduction of glyphosate into plants is through leaves. Increase in the speed of its absorption by the plants is facilitated by surfactants, moisture and temperature. Glyphosate absorbed by leaves easily travels to other parts of the plant, preventing its growth (Gottrup et al., 1976; Frank \& Tworkoski, 1994; Ganie et al., 2017).

The literature contains practically no information on the presence and amount of glyphosate in food products obtained through monitoring studies. The available information mostly relates to the results of field 
studies of preparations on the base of glyphosate. During use of glyphosate as a herbicide before sowing grain crops, its residue and the remains of its main metabolite, AMPA (aminomethylphosphonic acid), were not found at the level of finding threshold, which equals $0.05 \mathrm{mg} / \mathrm{kg}$ in grain of cereals during harvest. On grasses and beans before harvesting, glyphosate was found in grains of cereals and beans within $0.20-4.80 \mathrm{mg} / \mathrm{kg}$ (Mamy et al., 2005; Kuznetsova \& Chmil, 2010).

Industrial processing of agricultural production significantly reduces the content of glyphosate and its metabolites in it, but does not remove this pesticide completely. Also, glyphosate does not decompose during thermal processing of products (baking, boiling) (Kujawa, 1982; Kello, 1989; Kuznetsova \& Chmil, 2010). After introduction with fodders into the organism of animals, glyphosate is quickly removed without decomposition. In the experiments involving feeding different animals with fodders containing glyphosate in concentration of $100 \mathrm{mg} / \mathrm{kg}$, the residues of the active substance were found in meet of pigs, poultry and cattle in concentration less than $0.05 \mathrm{mg} / \mathrm{kg}$. In liver of these animals, glyphosate was found in the amount of $0.12 \mathrm{mg}$, whereas residue of glyphosate in milk of cattle was not found at all (Jones, 1994; Kuznetsova \& Chmil, 2010).

Determining the toxicity of glyphosate and preparations on its basis has been the subject of a large amount of studies. We know that for $\mathrm{LD}_{50}$ rats, it equals over $5,000 \mathrm{mg} / \mathrm{kg}$ of the animal's body weight at internal consumption, for rabbits $-3,800 \mathrm{mg} / \mathrm{kg}$, over $10,000 \mathrm{mg} / \mathrm{kg}$ for mice and $3,530 \mathrm{mg} / \mathrm{kg}$ for goats, it does not accumulate in the tissues of animals and does not irritate the skin (Glyphosate Technical Fact Sheet, http://npic.orst.edu/factsheets/archive/glyphotech.html). The safety measures during working with it are the same as for low-toxic pesticide, but one it is important that the solution does not get into the mucous membranes of the eye. Despite this, there are a number of publications (Bates \& Edwards, 2013; Gil et al., 2013; Cortinovis et al., 2015) on intoxication of people and animals with glyphosate and compounds which include it. The mechanisms of the toxicity of substances with glyphosate are complex and not fully determined. This is due to the fact that cases of intoxication have been not only with the active ingredient of herbicide, but complex compounds with its content.

The most commonly used food additives are preservatives, stabilizers and colourings. They are constantly included in food products in acceptable concentrations both separately and in combination (Behrens et al., 2017). The impact of these preparations on the organism of humans and animals is described in many studies. Most often, the preservative sodium benzoate, $\mathrm{C}_{6} \mathrm{H}_{5} \mathrm{COONa}$, is used, which has antimicrobial and fungicidal effect, has a strong inhibiting effect on yeasts and mold, inhibiting the activity of cellular enzymes which respond to the oxidativerestoration reactions and decompose fat and starch (Piper, 1999; Adeola \& Aworh, 2013). Sodium benzoate is considered generally safe, but there are data that constant consumption of it leads to disorders in concentration and hyperactivty, especially among children. Presumably this is related to the fact that it is a competitive inhibitor of D-amino acid oxidase which metabolizes D-serin, which takes an important part in neurotransmission via NMDA-receptor in the brain. And direct change in the level of D-serin by consumption of sodium benzoate, especially among children, can be one of the reasons for hyperactivity (Hashimoto, 2011).

There are data obtained in experiments with mice indicating that short-term consumption of sodium benzoate leads to memory loss and increase in stress (Khoshnoud et al., 2017). Also it has an immunemodeling potential. Such conclusion was drawn by Yadav et al. (2016) over the study of the impact of different doses of the preservative on the splenocytes and their property of expression of immune receptors and cytokines over three days.

The concentration of sodium benzoate, usually used in non-alcoholic beverages $(0.1 \%)$, causes significant reduction of viability of cellular cultures of neurons of the cerebral cortex of rats and epithelium of humans (Park et al., 2011). In a test on the genotoxicity of plants (SCGE-assay), the inhibitory effect of the benzoate on the synthesis of DNA in the cells of the root system of Vicia faba was determined (Njagi \& Gopalan, 1982).

Saccharin, $\mathrm{C}_{7} \mathrm{H}_{5} \mathrm{NO}_{3} \mathrm{~S}, \mathrm{E}_{954}$ is a food additive which is $300-500$ as sweet as sugar. It is widely used as sweetener in the production of noncalory and low calory food products (Roberts, 2016; Su-Ah et al., 2017). It has no nutritional properties, is not absorbed by the organism and is excreted with urine (Stanner, 2010). It is more commonly used in a mixture with other sweeteners (Behrens et al., 2017). There are also numerous reports about the effect of the sweeteners on health of humans and animals (Shwide-Slavin et al., 2012; Gong et al., 2016; Bourie et al., 2017; Boyko \& Brygadyrenko, 2017; Lohner et al., 2017; Martynov \& Brygadyrenko, 2017; Yamashita et al., 2017; Bissonnette et al., 2017; Chan et al., 2017; Bian et al., 2017a; Pinto et al., 2017). There are data that during consumption of sweeteners, healthy people were observed to have increased risk of cancer, diabetes, caries (Fowler, 2016; Lohner et al., 2017). There were reports on the carcenogenic properties of saccharin and risk of development of cancer of the urinary bladder, but further studies disproved this (Weihrauch \& Diehl, 2004; Vasconcelos et al., 2017). Non-calory sweeteners stimulate the development of intolerance of glucose by change in the microflora of the intestines and subsequent development of inflammatory processes in the organs (Suez et al., 2014; Nettleton et al., 2016; Qin, 2016; Bian et al., 2017b), and significantly reduce the sense of taste (Bakali et al., 2016; Sclafani \& Ackroff, 2017; Dess et al., 2017; Choo \& Dando, 2018). Despite these data, nowadays, saccharin is approved for ubiquitous usage in over 90 countries. The recommended dose is $5 \mathrm{mg} / \mathrm{kg}$ of human body weight and is considered harmless for health.

Saccharin and other sweeteners pose a greater threat to the environment, for they are pollutants along with pharmaceutical preparations, steroid hormones and pesticides (Kobetičová et al., 2016). Numerous studies indicate presence of artificial sweeteners in groundwater and open water bodies practically throughout the world (Vymazal \& Dvořáková Březinová, 2016; Brumovský et al., 2017; Edwards et al., 2017; Saurette et al., 2017; Snider et al., 2017; Yang et al., 2017).

Despite the fact that each described substance (glyphosate, sodium benzoate and saccharin) separately are considered safe, their combined effect on the growth of organism, development and condition of the organs and the systems over a particular period have not been studied. Therefore the objective of this study was to determine the impact of glyphosate in combination with food additives on the body weight, index of mass of the organs and biochemical parameters of blood of rats in the conditions of a laboratory experiment.

\section{Materials and methods}

All manipulations with animals were performed in accordance with the European Convention for the Protection of Vertebrate Animals used for Experimental and Other Scientific Purposes (Strasbourg, 1986; Kyiv, 2001). Putting the animals to death was performed according to the reqirements of the Law of Ukraine No. 3447-IV 21.02.2006 "On the protection of animals from abuse". As an antiseptic preparation, sodium thiopental was used $(40 \mathrm{mg} / \mathrm{kg}$ ). The protocol of the studies was agreed with the local ethics committee of Dnipro State Agrarian and Economic University.

The research were performed on outbred white male rats (60-96 g body weight) held in a vivarium of Dnipro State Agrarian and Economic University. Throughout the experiment, the rats were kept in standard conditions at the temperature of $20-22{ }^{\circ} \mathrm{C}$ on a balanced diet containing all necessary components. The animals were divided into four groups with five animals in each: I group - intact animals (control) consumed pure water, II group - rats were given $1 \%$ aqueous solution of glyphosate, the animals of III and IV groups in proportion 1:1 - $1 \%$ aqueous solution of glyphosate with $1 \%$ solution of sodium benzoate and $1 \%$ solution of glyphosate with $1 \%$ aqueous solution of saccharin, respectively. Drinking water (I group) and solutions (II-IV groups) were provided for the rats without any restrictions in glass drinking dishes of 0.1 liter. The experiment lasted 42 days. During the experiment, every three days, the mass of the animals was determined using the method of direct weighing with accuracy to $0.01 \mathrm{~g}$. In addition, we performed the consideration of the consumed water and solutions with following addition of its new portion for the animals.

At the end of the experiment, blood was withdrawn from the heart of the animals (right ventricle) under thiopental anaestesia $(40 \mathrm{mg} / \mathrm{kg}$ ). Biochemical parameters of the blood were determined using Miura 200 automatic biochemical analyzer with High Technology (USA), PZ Cor- 
may S.A. (Poland) and Spinreact S.A. (Spain) sets of reagents. We determined total protein - biuret test, albumins - in reactions with bromocresol green, globulins and protein coefficient - calculation method, uric acid - enzymically with uricase, activity of aspartate aminotransferase (AST) and alanine aminotrasferase (ALT) - using kinetic method based on Warburg's optical test, activity of alkaline phosphatase - enzymic method with $n$-nitrophenyl phosphate, total biliburin, glucose - enzymic glucose oxidase method. In the stabilized blood of rats, we determined the number of erythrocytes and leukocytes on an automatic hematological analyzer BC-2800Vet and Mindray. For removal of leukogram, we prepared blood smears according to Pappenheim followed by Romanovsky-Gimsa staining. After withdrawal of the animals from the experiment, through dissection, we selected the rats' organs (heart, liver, pancreas, lungs, kidneys, testis, brain, hematopoietic organs, stomach, intestines), weighed them using KERN-440-35A scales with $0.001 \mathrm{~g}$ accuracy and determined the indices of the mass of the internal organs.

The data were analyzed in Statistica 6.0 (StatSoft Inc., USA). The data in the tables are presented as $\mathrm{x} \pm \mathrm{SD}(\mathrm{x} \pm$ standard deviation). The differences between the values in the control and experimental groups were determined using the Tukey test, where the differences were considered significant at $\mathrm{P}<0.05$ (with taking into account the Bonferroni correction).

\section{Results}

During the experiment, the animals consumed the following amount of water: in group I - $8.38 \mathrm{ml} /$ individual a day, in group II - 2.16 , group III 6.59 , group IV $-8.76 \mathrm{ml} /$ individual a day. Glyphosate separately, and in combination with benzoate and saccharin caused a practically two times decrease in the daily gain in the animals' body weight compared to the control group (Table 1). It is interesting that the differences in the change in the body weight did not manifest under the impact of benzoate and saccharin, despite a 3.05 and 4.05-times increase in the amount of the consumed solution a day when these food additives were added.

Addition of glyphosate to the rats' diet caused reliable increase in the relative mass of the ileum and pancreas (Table 2) and decrease in the relative mass of the thymus, duodenum and large intestine. Addition of benzoate in addition to the variant of the experiment with glyphosate caused an increase in the relative mass of the lungs, small intestine in general and the jejunum and ileum in particular, and also decrease in the mass of the duodenum and rectum and thymus. Addition of glyphosate with saccharin to the rats' diet (Table 2) caused increase in the relative mass of the liver and jejunum, and also decrease in the mass of the duodenum and thymus.

Table 1

Change in the body weight (g/day) of male rats under the impact of adding glyphosate, benzoate and saccharin to their $\operatorname{diet}(\mathrm{x} \pm \mathrm{SD}, \mathrm{n}=60)$

\begin{tabular}{|c|c|c|c|c|c|}
\hline Group & $\begin{array}{l}\text { Average consumption of water or solutions } \\
\text { of the substances, g/day per animal }\end{array}$ & $\begin{array}{c}\text { Average daily increase } \\
\text { in animals' body weight, } \mathrm{g} / \text { day }\end{array}$ & $\begin{array}{l}\text { In relation to } \\
\text { control, } \%\end{array}$ & $\begin{array}{c}\mathrm{F} \\
\left(\text { at } \mathrm{F}_{0.05}=3.91\right)\end{array}$ & $P$ \\
\hline Control & 8.38 & $3.558 \pm 2.180$ & - & - & - \\
\hline Glyphosate, $1.0 \%$ & 2.16 & $1.914 \pm 1.582$ & 53.8 & 20.93 & $1.3 \cdot 10^{-5}$ \\
\hline Glyphosate, $1.0 \%$ + benzoate, $1.0 \%$ & 6.59 & $1.949 \pm 1.432$ & 54.8 & 23.82 & $3.3 \cdot 10^{-6}$ \\
\hline Glyphosate, $1.0 \%+$ saccharin, $1.0 \%$ & 8.76 & $1.930 \pm 1.572$ & 54.2 & 22.43 & $6.2 \cdot 10^{-6}$ \\
\hline
\end{tabular}

Table 2

Change in relative mass of the organs (\%) of male rats under the impact of adding glyphosate, benzoate and saccharin to their diet $(\mathrm{x} \pm \mathrm{SD}, \mathrm{n}=5$, duration of the experiment -42 days)

\begin{tabular}{|c|c|c|c|c|c|c|c|}
\hline Organ & Control & Glyphosate, $1.0 \%$ & $\begin{array}{l}\text { Glyphosate in } \\
\text { relation to control, \% }\end{array}$ & $\begin{array}{c}\text { Glyphosate, } 1.0 \%+ \\
\text { benzoate, } 1.0 \%\end{array}$ & $\begin{array}{c}\text { Glyphosate }+ \\
\text { benzoate in relation } \\
\text { to control, } \%\end{array}$ & $\begin{array}{c}\text { Glyphosate, } 1.0 \%+ \\
\text { saccharin, } 1.0 \%\end{array}$ & $\begin{array}{c}\text { Glyphosate }+ \\
\text { saccharin in relation } \\
\text { to control, } \%\end{array}$ \\
\hline Heart & $0.393 \pm 0.049^{\mathrm{a}}$ & $0.399 \pm 0.089^{\mathrm{a}}$ & 101.7 & $0.406 \pm 0.116^{\mathrm{a}}$ & 103.3 & $0.439 \pm 0.036^{\mathrm{a}}$ & 111.8 \\
\hline Lungs & $0.570 \pm 0.062^{\mathrm{a}}$ & $0.710 \pm 0.180^{\mathrm{a}}$ & 124.5 & $0.782 \pm 0.130^{\mathrm{ab}}$ & 137.0 & $0.763 \pm 0.220^{\mathrm{a}}$ & 133.7 \\
\hline Liver & $3.79 \pm 0.55^{\mathrm{a}}$ & $3.90 \pm 0.50^{\mathrm{a}}$ & 102.9 & $4.39 \pm 0.26^{\mathrm{a}}$ & 115.9 & $4.75 \pm 0.25^{\mathrm{ab}}$ & 125.2 \\
\hline Spleen & $0.431 \pm 0.139^{\mathrm{a}}$ & $0.356 \pm 0.042^{\mathrm{a}}$ & 82.6 & $0.314 \pm 0.018^{\mathrm{a}}$ & 72.8 & $0.344 \pm 0.026^{\mathrm{a}}$ & 79.9 \\
\hline Stomach & $0.707 \pm 0.152^{\mathrm{a}}$ & $0.750 \pm 0.162^{\mathrm{a}}$ & 106.1 & $0.719 \pm 0.150^{\mathrm{a}}$ & 101.8 & $0.781 \pm 0.167^{\mathrm{a}}$ & 110.5 \\
\hline Intestine & $5.81 \pm 0.74^{\mathrm{a}}$ & $5.51 \pm 1.30^{\mathrm{a}}$ & 94.9 & $6.69 \pm 1.01^{\mathrm{a}}$ & 115.3 & $5.90 \pm 0.94^{\mathrm{a}}$ & 101.6 \\
\hline Small intestine & $3.96 \pm 0.34^{\mathrm{a}}$ & $4.07 \pm 1.10^{\mathrm{a}}$ & 102.9 & $5.28 \pm 0.95^{\mathrm{ab}}$ & 133.2 & $4.29 \pm 0.77^{\mathrm{a}}$ & 108.4 \\
\hline - duodenum & $1.055 \pm 0.201^{\mathrm{a}}$ & $0.691 \pm 0.350^{\mathrm{b}}$ & 65.4 & $0.597 \pm 0.302^{\mathrm{b}}$ & 56.6 & $0.579 \pm 0.225^{\mathrm{b}}$ & 54.8 \\
\hline -jejunum & $2.53 \pm 0.18^{\mathrm{a}}$ & $2.81 \pm 0.73^{\mathrm{a}}$ & 110.9 & $3.83 \pm 0.74^{\mathrm{b}}$ & 151.1 & $3.34 \pm 0.51^{\mathrm{b}}$ & 131.8 \\
\hline -ileum & $0.371 \pm 0.139^{\mathrm{a}}$ & $0.571 \pm 0.398^{\mathrm{b}}$ & 154.0 & $0.851 \pm 0.322^{\mathrm{b}}$ & 229.2 & $0.374 \pm 0.279^{\mathrm{a}}$ & 100.9 \\
\hline Large intestine & $1.976 \pm 0.451^{\mathrm{a}}$ & $1.433 \pm 0.348^{\mathrm{ab}}$ & 72.5 & $1.327 \pm 0.136^{\mathrm{ab}}$ & 67.1 & $1.606 \pm 0.203^{\mathrm{a}}$ & 81.3 \\
\hline - caecum & $0.628 \pm 0.209^{\mathrm{a}}$ & $0.438 \pm 0.098^{\mathrm{a}}$ & 69.7 & $0.480 \pm 0.109^{\mathrm{a}}$ & 76.4 & $0.496 \pm 0.124^{\mathrm{a}}$ & 79.0 \\
\hline - upper colon & $0.860 \pm 0.223^{\mathrm{a}}$ & $0.857 \pm 0.265^{\mathrm{a}}$ & 99.7 & $0.722 \pm 0.084^{\mathrm{a}}$ & 84.0 & $0.921 \pm 0.103^{\mathrm{a}}$ & 107.1 \\
\hline - rectum & $0.214 \pm 0.088^{\mathrm{a}}$ & $0.138 \pm 0.048^{\mathrm{a}}$ & 64.3 & $0.125 \pm 0.020^{\mathrm{ab}}$ & 58.1 & $0.189 \pm 0.045^{\mathrm{a}}$ & 88.1 \\
\hline Right kidney & $0.400 \pm 0.062^{\mathrm{a}}$ & $0.390 \pm 0.037^{\mathrm{a}}$ & 97.5 & $0.375 \pm 0.042^{\mathrm{a}}$ & 93.7 & $0.404 \pm 0.061^{\mathrm{a}}$ & 100.9 \\
\hline Left kidney & $0.417 \pm 0.078^{\mathrm{a}}$ & $0.389 \pm 0.036^{\mathrm{a}}$ & 93.4 & $0.375 \pm 0.028^{\mathrm{a}}$ & 90.1 & $0.393 \pm 0.048^{\mathrm{a}}$ & 94.3 \\
\hline Testis & $0.699 \pm 0.171^{\mathrm{a}}$ & $0.695 \pm 0.064^{\mathrm{a}}$ & 99.5 & $0.690 \pm 0.080^{\mathrm{a}}$ & 98.8 & $0.725 \pm 0.072^{\mathrm{a}}$ & 103.8 \\
\hline Thymus & $0.325 \pm 0.065^{\mathrm{a}}$ & $0.231 \pm 0.063^{\mathrm{b}}$ & 70.9 & $0.168 \pm 0.051^{\mathrm{b}}$ & 51.8 & $0.187 \pm 0.079^{b}$ & 57.6 \\
\hline Pancreas & $0.403 \pm 0.097^{\mathrm{a}}$ & $0.609 \pm 0.210^{b}$ & 151.1 & $0.631 \pm 0.094^{b}$ & 156.7 & $0.499 \pm 0.077^{\mathrm{a}}$ & 124.0 \\
\hline Brain & $0.839 \pm 0.140^{\mathrm{a}}$ & $0.896 \pm 0.149^{\mathrm{a}}$ & 106.9 & $0.789 \pm 0.136^{\mathrm{a}}$ & 94.1 & $0.909 \pm 0.117^{\mathrm{a}}$ & 108.4 \\
\hline
\end{tabular}

Note: different letters indicate the values significantly differing one from another within a line of the Table on the results of comparison using the Tukey test $(\mathrm{P}<0.05)$ with Bonferroni correction.

Addition of glyphosate to the rats' diet (Table 3) reliably caused increase in the concentration of albumins, activity of alkaline phosphatese, and also concentration of glucose and decrease in the concentration of cholesterol in the blood. Addition to glyphosate of benzoate caused much greater changes in biochemical parameters of the blood of male rats: increase in concentration of total protein, albumins and globulins, urine and urea nitrogen, activity of alkaline phosphatase and glucose. We should note a practically five times increase in the level of glucose in the variant with glyphosate and benzoate in comparison to the control group. Also, we observed a five-times reduction in the activity of aspartate aminotransferase (AST) in this variant of the experiment. Mixture of glyphosate and saccharin (Table 3) caused decrease in the concentration of globulins and cholesterol, and also increase in the same characteristics as glyphosate and benzoate.

Addition of glyphosate, benzoate and saccharin reliably decreased the amount of erythrocytes per unit of blood volume (Table 4). Decrease in leukocytes under the impact of glyphosate is compensated and increased with the addition of benzoate into the diet. It should be mentioned that there was significant decrease in the percentage of microxyphil neutrophils and increase in the percentage of lymphocytes in all variants of the experiment with glyphosate, benzoate and saccharin compared to the control (Table 4). 
Table 3

Change in biochemical parameters of blood of male rats under the impact of addition of glyphosate, benzoate and saccharin to their diet $(\mathrm{x} \pm \mathrm{SD}, \mathrm{n}=5$, the duration of the experiment -42 days)

\begin{tabular}{|c|c|c|c|c|c|c|c|}
\hline Indices & Control & Glyphosate, $1.0 \%$ & $\begin{array}{l}\text { Glyphosate in } \\
\text { relation to control, \% }\end{array}$ & $\begin{array}{c}\text { Glyphosate, } 1.0 \%+ \\
\text { benzoate, } 1.0 \%\end{array}$ & $\begin{array}{c}\text { Glyphosate }+ \\
\text { benzoate in relation } \\
\text { to control, } \%\end{array}$ & $\begin{array}{c}\text { Glyphosate, } 1.0 \%+ \\
\text { saccharin, } 1.0 \%\end{array}$ & $\begin{array}{c}\text { Glyphosate }+ \\
\text { saccharin in relation } \\
\text { to control, } \%\end{array}$ \\
\hline Total protein, $\mathrm{g} / \mathrm{L}$ & $61.4 \pm 10.3^{\mathrm{a}}$ & $69.0 \pm 3.9^{\mathrm{a}}$ & 112.4 & $81.2 \pm 8.3^{b}$ & 132.2 & $65.5 \pm 3.1^{\mathrm{a}}$ & 106.7 \\
\hline Albumins, $\mathrm{g} / \mathrm{L}$ & $28.8 \pm 6.8^{\mathrm{a}}$ & $36.6 \pm 0.9^{\mathrm{ab}}$ & 127.1 & $42.2 \pm 6.2^{\mathrm{b}}$ & 146.5 & $36.5 \pm 1.9^{\mathrm{a}}$ & 126.7 \\
\hline Globulins, g/L & $32.8 \pm 6.0^{\mathrm{a}}$ & $32.4 \pm 3.9^{\mathrm{a}}$ & 98.8 & $39.0 \pm 3.8^{\mathrm{ab}}$ & 118.9 & $29.0 \pm 2.9^{\mathrm{ac}}$ & 88.4 \\
\hline Protein coefficient, units & $0.87 \pm 0.23^{\mathrm{a}}$ & $1.14 \pm 0.15^{\mathrm{a}}$ & 131.6 & $1.10 \pm 0.14^{\mathrm{a}}$ & 127.0 & $1.28 \pm 0.13^{\mathrm{ab}}$ & 147.2 \\
\hline Urea, mmol/L & $7.12 \pm 1.69^{\mathrm{a}}$ & $6.96 \pm 1.59^{\mathrm{a}}$ & 97.8 & $9.38 \pm 0.18^{b}$ & 131.7 & $7.93 \pm 1.41^{\mathrm{ab}}$ & 111.3 \\
\hline Urea nitrogen, $\mathrm{mg} \%$ & $13.2 \pm 3.2^{\mathrm{a}}$ & $13.3 \pm 3.1^{\mathrm{a}}$ & 101.2 & $17.9 \pm 0.3^{b}$ & 136.3 & $15.2 \pm 2.7^{\mathrm{ab}}$ & 115.1 \\
\hline $\begin{array}{l}\text { Aspartate aminotransferase } \\
\text { (AST), U/L }\end{array}$ & $153.4 \pm 101.5^{\mathrm{a}}$ & $269.8 \pm 119.3^{\mathrm{a}}$ & 175.9 & $27.6 \pm 7.0^{\mathrm{b}}$ & 18.0 & $290.0 \pm 70.8^{\mathrm{a}}$ & 189.0 \\
\hline $\begin{array}{l}\text { Alanine aminotransferase } \\
(\mathrm{ALT}), \mathrm{U} / \mathrm{L}\end{array}$ & $62.8 \pm 37.7^{\mathrm{a}}$ & $91.8 \pm 82.3^{\mathrm{a}}$ & 146.2 & $49.4 \pm 95.4^{\mathrm{a}}$ & 78.7 & $125.3 \pm 82.5^{\mathrm{a}}$ & 199.4 \\
\hline De Ritis Ratio, U & $2.68 \pm 1.25^{\mathrm{a}}$ & $3.70 \pm 1.93^{\mathrm{a}}$ & 138.1 & $3.20 \pm 2.23^{\mathrm{a}}$ & 119.4 & $3.10 \pm 1.65^{\mathrm{a}}$ & 115.7 \\
\hline Alkaline phosphatase, $\mathrm{U} / \mathrm{L}$ & $260.4 \pm 92.0^{\mathrm{a}}$ & $492.9 \pm 64.9^{b}$ & 189.3 & $447.6 \pm 199.4^{\mathrm{ab}}$ & 171.9 & $437.3 \pm 59.9^{\mathrm{ab}}$ & 167.9 \\
\hline Total bilirubin, $\mu \mathrm{mol} / \mathrm{L}$ & $8.1 \pm 3.5^{\mathrm{a}}$ & $8.3 \pm 4.1^{\mathrm{a}}$ & 103.0 & $13.0 \pm 5.4^{\mathrm{a}}$ & 161.0 & $7.6 \pm 1.2^{\mathrm{a}}$ & 94.6 \\
\hline Glucose, $\mathrm{mmol} / \mathrm{L}$ & $5.7 \pm 1.2^{\mathrm{a}}$ & $11.5 \pm 5.5^{\mathrm{b}}$ & 201.4 & $28.3 \pm 11.2^{\mathrm{c}}$ & 495.5 & $10.4 \pm 4.9^{\mathrm{ab}}$ & 181.4 \\
\hline Cholesterol, $\mathrm{mmol} / \mathrm{L}$ & $1.78 \pm 0.23^{\mathrm{a}}$ & $1.08 \pm 0.16^{\mathrm{b}}$ & 60.7 & $1.02 \pm 0.19^{b}$ & 57.3 & $1.05 \pm 0.33^{\mathrm{b}}$ & 59.0 \\
\hline
\end{tabular}

Note: see Table 1.

\section{Table 4}

Change in the general analysis of blood and leukogram of male rats under the impact of adding glyphosate, benzoate and saccharin to their $\operatorname{diet}(\mathrm{x} \pm \mathrm{SD}, \mathrm{n}=5$, the duration of experiment -42 days)

\begin{tabular}{|c|c|c|c|c|c|c|c|}
\hline Indices & Control & Glyphosate, $1.0 \%$ & $\begin{array}{c}\text { In relation to } \\
\text { control, } \%\end{array}$ & $\begin{array}{c}\text { Glyphosate, } 1.0 \%+ \\
\text { benzoate, } 1.0 \% \\
\end{array}$ & $\begin{array}{c}\text { In relation to } \\
\text { control, } \%\end{array}$ & $\begin{array}{c}\text { Glyphosate, } 1.0 \%+ \\
\text { saccharin, } 1.0 \% \\
\end{array}$ & $\begin{array}{c}\text { In relation to } \\
\text { control, } \%\end{array}$ \\
\hline Hemoglobin, $\mathrm{g} / \mathrm{L}$ & $127.0 \pm 9.9^{\mathrm{a}}$ & $90.4 \pm 10.0^{b}$ & 71.2 & $115.0 \pm 11.1^{\mathrm{a}}$ & 90.6 & $90.5 \pm 13.2^{\mathrm{b}}$ & 71.3 \\
\hline Erythrocytes, $10^{12} / \mathrm{L}$ & $7.87 \pm 0.55^{\mathrm{a}}$ & $4.95 \pm 0.79^{b}$ & 62.9 & $6.05 \pm 1.46^{\mathrm{ab}}$ & 76.9 & $4.18 \pm 0.35^{\mathrm{b}}$ & 53.1 \\
\hline Leukocytes, $10^{9} / \mathrm{L}$ & $6.77 \pm 0.63^{\mathrm{a}}$ & $4.44 \pm 0.35^{\mathrm{ab}}$ & 65.6 & $9.94 \pm 4.31^{\mathrm{a}}$ & 146.8 & $5.43 \pm 1.95^{\mathrm{a}}$ & 80.1 \\
\hline \multicolumn{8}{|l|}{ Leukogram } \\
\hline \multicolumn{8}{|l|}{ Neutrophiles, $\%$} \\
\hline - neutrophiles segmented & $34.14 \pm 6.01^{\mathrm{a}}$ & $7.40 \pm 3.44^{\mathrm{b}}$ & 21.7 & $10.20 \pm 6.14^{b}$ & 29.9 & $4.75 \pm 2.63^{\mathrm{b}}$ & 13.9 \\
\hline - neutrophiles banded & $2.71 \pm 1.50^{\mathrm{a}}$ & $1.40 \pm 0.55^{\mathrm{a}}$ & 51.6 & $1.80 \pm 1.64^{\mathrm{a}}$ & 66.3 & $1.25 \pm 0.50^{\mathrm{a}}$ & 46.1 \\
\hline - neutrophiles juvenile & $0.00 \pm 0.00^{\mathrm{a}}$ & $0.00 \pm 0.00^{\mathrm{a}}$ & - & $0.00 \pm 0.00^{\mathrm{a}}$ & - & $0.00 \pm 0.00^{\mathrm{a}}$ & - \\
\hline Eosinophils, $\%$ & $1.00 \pm 0.82^{\mathrm{a}}$ & $0.40 \pm 0.98^{\mathrm{a}}$ & 40.0 & $0.80 \pm 1.30^{\mathrm{a}}$ & 80.0 & $0.75 \pm 0.96^{\mathrm{a}}$ & 75.0 \\
\hline Lymphocytes, \% & $60.1 \pm 5.3^{\mathrm{a}}$ & $87.2 \pm 3.3^{b}$ & 145.0 & $82.4 \pm 9.8^{b}$ & 137.0 & $89.5 \pm 1.7^{b}$ & 148.8 \\
\hline Monocytes, \% & $2.29 \pm 1.11^{\mathrm{a}}$ & $3.60 \pm 1.52^{\mathrm{a}}$ & 157.5 & $4.80 \pm 3.03^{\mathrm{a}}$ & 210.0 & $3.75 \pm 1.50^{\mathrm{a}}$ & 164.1 \\
\hline
\end{tabular}

Note: see Table 1.

\section{Discussion}

Glyphosate affects the energy metabolism in the organism, particularly mitochondria of liver cells of rats (Olorunsogo et al., 1979), biotransformation of substances, reduces the activity of some enzymes of the cells in vivo (Hietanen et al., 2009) and in vitro (El-Demerdash et al., 2001). Increase in the mass of liver under the impact of glyphosate was observed in a chronic experiment at long term consumption of high doses $(940 \mathrm{mg} / \mathrm{kg} \cdot$ day) of the substances among rats (Stout \& Ruecker, 1993. Chronic study of glyphosate administered in feed to albino rats. Unpublished Report no. MSL-10495 R.D. 1014, 1990, submitted to U.S. Environmental Protection Agency by Monsanto Agricultural Company). In our experiment, glyphosate caused no change in the relative mass of liver, whereas with addition of food additives, we observed an increase in this parameter, especially with addition of saccharin to the diet. The impact of pesticide and food additives on the liver system is also indicated by changes of biochemical parameters of blood. A significant increase was observed in the content of the total protein in the blood with combined consumption of glyphosate and sodium benzoate, due to increase in the albumin fraction, whereas with usage of saccharin, the level of globulins rapidly decreased, which was followed by change in the protein coefficient.

Glyphosate in the content of Roundup negatively affects the activity of enzymes of mammals. It creates disbalance in the activity of enzymes in the organism, which is extremely dangerous for animals at especially sensitive stages of ontogenesis. Herbicide causes blocking of the enzymes necessary for normal metabolism, particularly for enzymes of the intestine which allow removal of toxins from the organism. According to the results of Dutch scientists (http://dca.au.dk/fileadmin/DJF/DCA/Notat om GM_foder_til_husdyr_20140204.pdf), two hypotheses on the impact of glyphosate on the enzymic systems of animals were drawn. According to them, glyphosate affects the microorganisms of the gastro-internal tract, which in turn effects productivity and health. Also it was presumed that the herbicide causes disorder in mineral metabolism, which indirectly leads to health problems. In our experiment, we have also observed disbalance in the activity of enzymes of blood in the experimental groups of animals. In particular, increase in AST against the background of the glyphosate and mixture of glyphosate with saccharin, and steep decrease in the activity of AST at usage of a mixture of glyphosate and benzoate, reliable increase in the activity of alkaline phosphatase occurred in all variants of the experiment.

In our experiment, we found a significant impact of glyphosate and its mixtures with food additives on the condition of pancreas. Accordingly, the relative mass of the organ significantly increases with consumption of glyphosate and mixture of glyphosate with benzoate, and unreliably - in animals which received glyphosate with saccharin. Reliable increase in the level of glucose in blood of rats of the experimental groups along with increase in the relative mass of the pancreas indicates the negative impact of glyphosate itself and its mixtures with food additives.

Among humans, deliberate intoxications with glyphosate (internal consumption of over $85 \mathrm{ml}$ of concentrated compound) cause significant toxicity which manifests in severe disorders of practically all systems of the organism (Sørensen \& Gregersen, 1999; Lee et al., 2000). Cases of lethal outcome after consuming high doses of this substance have been descrybed (Stella \& Ryan, 2004; Lee \& Guo, 2011). Accidental consumption of glyphosate compounds usually leads to insignificant damages to the respiratory and digestive systems and are easily treated (Gil et al., 2013). A contact impact can cause skin lesions, the effect on the eyes is usually short term, and usually, causes no complications (Acquavella et al., 1999; Amerio et al., 2004). In domestic animals, particularly dogs and cats, the impact of glyphosate-containing products leads to state of anxiety, dis- 
orders of the gastro-intestinal and respiratory apparatuses, which manifest in vomiting, hypersalivation, diarhea, tachypnea, whereas prostration and paresis are more rarely observed (Bates \& Edwards, 2013; Cortinovis et al., 2015). Also, the animals were observed to have increase in relative mass of lungs in all three experimental groups of our study. These data are interesting and require further analysis.

The literature includes statements about possible carcinogenic impact of glyphosate and its long-term impact on humans (Bolognes et al., 2009; Guyton et al., 2015) and laboratory animals (Cressey, 2015). Glyphosate can cause chromosome aberrations as a result of damaging the DNA of cells of human and animals in vitro. Also, there are results which disprove these statements: no persuasive evidences of its toxicity in acute, subchronic and chronic studies were found, oncogenic potential of glyphosate was not proved, and no impact on the fertility or reproductive functions of humans and other mammals was found (Williams et al., 2000).

Today, glyphosate is considered non-toxic and is allowed to be used ubiquitously. Despite the fact that this herbicide and preparations which contain it in general are harmless for humans and animals, it is constantly introduced into their organism. This is especially relevant for people who deal with it directly, for example farmers and members of their families. It was proved that residues of glyphosate are present in their urine on the day of using the herbicide, as well as some time after its usage (Acquavella et al., 2004). Therefore, research on the combined effect of glyphosate and other substances on the organism of humans and animals is a subject of interest.

In an experiment on laboratory outbred white male rats of three age groups, the combined impact of glyphosate (in the form of the Roundup herbicide) with salts of heavy metals on the immune system was determined. It was found that there was an increase in the content of circulating immune complexes and a decrease in the concentration of immune globulins in all age groups of the studied animals (Dmuhal'skaja, 2018). In our experiment, we also determined the negative effect of the herbicide separately and of its mixtures with food additives on the immune system of rats. This manifested in a reliable steep decrease in relative mass of the central organ of the immune system - the thymus of animals of all three experimental groups and an unreliable decrease of this parameter for the spleen, a secondary organ of the immune protection. Also, the condition of the immune system is indicated by the level of globulins in the blood - a decrease in their amount in animals which received glyphosate (below the physiological norm) and glyphosate with saccharin (below the physiological norm compared to the control group). Inhibition of the activity of the red bone marrow may be also indicated indirectly by the low level of hemoglobin and erythrocytes in animals of all experimental groups in comparison with the control. These results are interesting and require further more detailed studies on the tissue and cellular levels of organisation of these organs.

Rats poisoned with Roundup $\left(1 / 100\right.$ and $\left.1 / 10000 \mathrm{LD}_{50}\right)$ against the background of prior ionising radiation were observed to have the stage of primary decompensation (1-18th day) naturally transforming into the stage of compensation and adaptation (18-30th day). The toxicity of Roundup and substances it contains (glyphosate, polyoxyethyleneamine) after intratracheal and peroral introduction to rats was determined. Combined toxicity of these substances is higher than of glyphosate (Adam et al., 1997).

\section{Conclusion}

The main factor of reduction of the intensity of gain in the rats' body weight is the slowing of the energy metabolism in the cells under the impact of glyphosate against the background of absence of reliable impact on the slowing of the anabolic processes caused by sodium benzoate and saccharine. All the studied substances have a notable immunesuppressive effect, the mechanism of which can be conditioned by the effect of accidental involution of lymphoid thymus parenchyma, which is proved by steep increase in the amount of lymphocytes in the peripheral blood of animals in combination with decrease in the organ's mass. Also, these substances have a negative effect on the processes of universal hematopoiesis in general, including the number of erythrocyteand myelocytopoiesis.
Change in the mass of the organs of animals under the impact of glyphosate is the consequence of the effect of this substance - irritation of the mucous membranes, intensifying of the processes of desquamation of intestinal epithelium with development of mild desquamative catarrhal enteritis, and also severe pancreatitis.

Simultaneous impact on the organs of rats caused by glyphosate, sodium benzoate and saccharine is followed by steep reduction of the reabsorption of the two latter components through "irritation" of mucous membrane by glyphosate with reduction of the effect of their systemic action. The main manifestations of the systemic action of benzoate on the rats' organism are development of myocardial dystrophy, edema of lungs and hepatodystrophy. Systematic impact of saccharin, first of all, causes formation of degenerative changes in liver parenchyma.

The results of biochemical examination of blood demonstrate that all three substances have a negative impact on liver parenchyma, which is manifested to a different extent. Glyphosate causes development of reversible dystrophic processes such as granular dystrophy. In combination with sodium benzoate and saccharin, the rats were observed to have signs of toxic hepatodystrophy or massive progressive necrosis of liver parenchyma, that is the processes which combine deep dystrophic and necrotic, often irreversible, processes.

Promising aspects of further studies are the determination of histological, histochemical and immune-histochemical changes in the organs of laboratory animals under the impact of glyphosate against the background of consumption of food additives.

\section{References}

Acquavella, J. F., Alexander, B. H., Mandel, J. S., Gustin, C., Baker, B., Chapman, P., \& Bleeke, M. (2004). Glyphosate biomonitoring for farmers and their families: Results from the farm family exposure study. Environmental Health Perspectives, 112(3), 321-326.

Acquavella, J. F., Weber, J. A., Cullen, M. R., Cruz, O. A., Martens, M. A., Holden, L. R., Riordan, S, Thompson, M., \& Farmer, D. (1999). Human ocular efects from self-reported exposures to Roundup ${ }^{\circledR}$ herbicides. Human and Experimental Toxicology, 18(8), 479-486.

Adam, A., Marzuki, A., Abdul Rahman, H., \& Abdul Aziz, M. (1997). The oral and intratracheal toxicities of Roundup and its components to rats. Veterinary and Human Toxicology, 39(3), 147-151.

Adeola, A. A., \& Aworh, O. C. (2013). Effects of sodium benzoate on storage stability of previously improved beverage from tamarind (Tamarindus indica L.). Food Science and Nutrition, 2(1), 17-27.

Amerio, P., Motta, A., Toto, P., Pour, S. M., Pajand, R., Feliciani, C., \& Tulli, A. (2004). Skin toxicity from glyphosate-surfactant formulation. Journal of Toxicology: Clinical Toxicology, 42(3), 317-319.

Bakali, E., Hong, J., Gillespie, J., \& Tincello, D. (2016). Saccharin increases perception of bladder filling in a forced diuresis experiment. Neurourology and Urodynamics, 36(5), 1363-1368.

Bates, N., \& Edwards, N. (2013). Glyphosate toxicity in animals. Clinical Toxicology, 51(10), 1243-1243.

Benbrook, C. M. (2016). Trends in glyphosate herbicide use in the United States and globally. Environmental Sciences Europe, 28(3), 1-15.

Behrens, M., Blank, K., \& Meyerhof, W. (2017). Blends of non-caloric sweeteners saccharin and cyclamate show reduced off-taste due to TAS2R bitter receptor inhibition. Cell Chemical Biology, 24(10), 1199-1204.

Bradberry, S. M., Proudfoot, A. T., \& Vale, J. A. (2004). Glyphosate poisoning. Toxicological Reviews, 23(3), 159-167.

Bian, X., Chi, L., Gao, B., Tu, P., Ru, H., \& Lu, K. (2017a). The artificial sweetener acesulfame potassium affects the gut microbiome and body weight gain in CD-1 mice. PLoS One, 12(6), e0178426.

Bian, X., Tu, P., Chi, L., Gao, B., Ru, H., \& Lu, K. (2017b). Saccharin induced liver inflammation in mice by altering the gut microbiota and its metabolic functions. Food and Chemical Toxicology, 107, 530-539.

Bissonnette, D. J., List, S., Knoblich, P., \& Hadley, M. (2017). The effect of nonnutritive sweeteners added to a liquid diet on volume and caloric intake and weight gain in rats. Obesity, 25(9), 1556-1563.

Bolognesi, C., Carrasquilla, G., Volpi, S., Solomon, K. R., \& Marshall, E. J. P. (2009). Biomonitoring of genotoxic risk in agricultural workers from five Colombian regions: Association to occupational exposure to glyphosate. Journal of Toxicology and Environmental Health, Part A, 72(15-16), 986-997.

Bourie, F., Olsson, K., Iskhakov, B., Buras, A., Fazilov, G., Shenouda, M., Zhezherya, J., \& Bodnar, R. J. (2017). Murine genetic variance in muscarinic cholinergic receptor antagonism of sucrose and saccharin solution intakes in three inbred mouse strains. Pharmacology Biochemistry and Behavior, 163, $50-56$. 
Boyko, A. A., \& Brygadyrenko, V. V. (2017). Changes in the viability of the eggs of Ascaris suum under the influence of flavourings and source materials approved for use in and on foods. Biosystems Diversity, 25(2), 162-166.

Brumovský, M., Bečanová, J., Kohoutek, J., Borghini, M., \& Nizzetto, L. (2017). Contaminants of emerging concern in the open sea waters of the Western Mediterranean. Environmental Pollution, 229, 976-983.

Chan, C. B., Hashemi, Z., \& Subhan, F. B. (2017). The impact of low and no-caloric sweeteners on glucose absorption, incretin secretion, and glucose tolerance. Applied Physiology, Nutrition, and Metabolism, 42(8), 793-801.

Choo, E., \& Dando, R. (2018). No detriment in taste response or expression in offspring of mice fed representative levels of sucrose or non-caloric sucralose while pregnant. Physiology and Behavior, 184, 39-45.

Cortinovis, C., Davanzo, F., Rivolta, M., \& Caloni, F. (2015). Glyphosate-surfactant herbicide poisoning in domestic animals: An epidemiological survey. Veterinary Record, 176(16), 413-413.

Cressey, D. (2015). Widely used herbicide linked to cancer. Nature, 24 March 2015, 1-3.

Dess, N. K., Dobson, K., Roberts, B. T., \& Chapman, C. D. (2017). Sweetener Intake by rats selectively bred for differential saccharin intake: Sucralose, stevia, and acesulfame potassium. Chemical Senses, 42(5), 381-392.

Dmuhal'skaja, E. B. (2018). Costojanie immunnoj sistemy u krys raznogo vozrasta pri dejstvii tjazhelyh metallov i raundapa [The state of the immune system in different age rats affected by the heavy metals and roundup]. Universum: Himija i Biologija, 51(9), $4-6$ (in Russian).

Edwards, Q. A., Kulikov, S. M., Garner-O’Neale, L. D., Metcalfe, C. D., \& Sultana, T. (2017). Contaminants of emerging concern in surface waters in Barbados, West Indies. Environmental Monitoring and Assessment, 189(12), 636.

El-Demerdash, F. M., Yousef, M. I., \& Elagamy, E. I. (2001). Influence of paraquat, glyphosate, and cadmium on the activity of some serum enzymes and protein electrophoretic behavior (in vitro). Journal of Environmental Science and Health, Part B, 36(1), 29-42.

Frank, J. R., \& Tworkoski, T. J. (1994). Response of canada thistle (Cirsium arvense) and leafy spurge (Euphorbia esula) clones to chlorsulfuron, clopyralid, and glyphosate. Weed Technology, 8(3), 565-571.

Fowler, S. P. G. (2016). Low-calorie sweetener use and energy balance: Results from experimental studies in animals, and large-scale prospective studies in humans. Physiology and Behavior, 164, 517-523.

Gottrup, O., O’sullivan, P. A., Schraa, R. J., \& Vanden, W. H. (1976). Uptake, translocation, metabolism and selectivity of glyphosate in canada thistle and leafy spurge. Weed Research, 16(3), 197-201.

Ganie, Z. A., Jugulam, M., \& Jhala, A. J. (2017). Temperature influences efficacy, absorption, and translocation of 2,4-D or glyphosate in glyphosate-resistant and glyphosate-susceptible common ragweed (Ambrosia artemisiifolia) and giant ragweed (Ambrosia trifida). Weed Science, 65(5), 588-602.

Gardner, J. G., \& Nelson, G. C. (2008). Herbicides, glyphosate resistance and acute mammalian toxicity: Simulating an environmental effect of glyphosate-resistant weeds in the USA. Pest Management Science, 64(4), 470-478.

Gil, H.-W., Park, J.-S., Park, S.-H., \& Hong, S.-Y. (2013). Effect of intravenous lipid emulsion in patients with acute glyphosate intoxication. Clinical Toxicology, 51(8), 767-771.

Gong, T., Wei, Q.-W., Mao, D.-G., Nagaoka, K., Watanabe, G., Taya, K., \& Shi, F.-X. (2016). Effects of daily exposure to saccharin and sucrose on testicular biologic functions in mice. Biology of Reproduction, 95(6), 116-116.

Guyton, K. Z., Loomis, D., Grosse, Y., El Ghissassi, F., Benbrahim-Tallaa, L., Guha, N., Scoccianti, C., Mattock, H., \& Straif, K. (2015). Carcinogenicity of tetrachlorvinphos, parathion, malathion, diazinon, and glyphosate. The Lancet Oncology, 16(5), 490-491.

Hashimoto, K. (2011). Food coloring, sodium benzoate preservative, and Dserine: Implications for behavior. In: Preedy, V. R., Watson, R. R., \& Martin, C. R. (Ed.). Handbook of behavior, food and nutrition. Springer, New York. Pp. 577-584.

Hietanen, E., Linnainmaa, K., \& Vainio, H. (2009). Effects of phenoxyherbicides and glyphosate on the hepatic and intestinal biotransformation activities in the rat. Acta Pharmacologica et Toxicologica, 53(2), 103-112.

Jones, K. C. (1994). International programme on chemical safety (IPCS) environmental health criteria. Environmental Pollution, 84(2), 203.

Kello, D. (1989). WHO drinking water quality guidelines for selected herbicides. Food Additives and Contaminants, 6(sup001), 79-85.

Khoshnoud, M. J., Siavashpour, A., Bakhshizadeh, M., \& Rashedinia, M. (2017). Effects of sodium benzoate, a commonly used food preservative, on learning, memory, and oxidative stress in brain of mice. Journal of Biochemical and Molecular Toxicology, 32(2), e22022.

Kniss, A. R. (2017). Long-term trends in the intensity and relative toxicity of herbicide use. Nature Communications, 8, 1-7.

Kobetičová, K., Mocová, K. A., Mrhálková, L., Fryčová, Z., \& Kočí, V. (2016). Artificial sweeteners and the environment. Czech Journal of Food Sciences, 34(2), 149-153.
Kujawa, M. (1982). FAO plant production and protection paper 20, pesticide residues in food; report 1979, 90 seiten. Food and Agriculture Organization of the United Nations, Rome 1980. Food / Nahrung, 26(2), 215-216.

Kuznetsova, E. M., \& Chmil, V. D. (2010). Glyphosate: Environmental fate and levels of residues. Modern Problems of Toxicology Food and Chemical Safety, 48(1), 87-95.

Lee, H.-L., Chen, K.-W., Chi, C.-H., Huang, J.-J., \& Tsai, L.-M. (2000). Clinical presentations and prognostic factors of a glyphosate-surfactant herbicide intoxication. A review of 131 cases. Academic Emergency Medicine, 7(8), 906-910.

Lee, H.-L., \& Guo, H.-R. (2011). The hemodynamic effects of the formulation of glyphosate-surfactant herbicides. In: Larramendy, M. (Ed.). Herbicides, theory and applications. IntechOpen, Rijeka. Pp. 545-566.

Lohner, S., Toews, I., \& Meerpohl, J. J. (2017). Health outcomes of non-nutritive sweeteners: Analysis of the research landscape. Nutrition Journal, 16(1), 1-21.

Mamy, L., Barriuso, E., \& Gabrielle, B. (2005). Environmental fate of herbicides trifluralin, metazachlor, metamitron and sulcotrione compared with that of glyphosate, a substitute broad spectrum herbicide for different glyphosateresistant crops. Pest Management Science, 61(9), 905-916.

Martynov, V. O., \& Brygadyrenko, V. V. (2017). The influence of synthetic food additives and surfactants on the body weight of larvae of Tenebrio molitor (Coleoptera, Tenebrionidae). Biosystems Diversity, 25(3), 236-242.

Nettleton, J. E., Reimer, R. A., \& Shearer, J. (2016). Reshaping the gut microbiota: Impact of low calorie sweeteners and the link to insulin resistance? Physiology and Behavior, 164, 488-493.

Njagi, G. D. E., \& Gopalan, H. N. B. (1982). Cytogenetic effects of the food preservatives - Sodium benzoate and sodium sulphite on Vicia faba root meristems. Mutation Research/Genetic Toxicology, 102(3), 213-219.

Olorunsogo, O. O., Bababunmi, E. A., \& Bassir, O. (1979). Effect of glyphosate on rat liver mitochondria in vivo. Bulletin of Environmental Contamination and Toxicology, 22(1), 357-364.

Park, H.-W., Park, E. H., Yun, H.-M., \& Rhim, H. (2011). Sodium benzoatemediated cytotoxicity in mammalian cells. Journal of Food Biochemistry, 35(4), 1034-1046.

Pinto, D. E., Foletto, K. C., Nunes, R. B., Lago, P. D., \& Bertoluci, M. C. (2017) Long-term intake of saccharin decreases post-absortive energy expenditure at rest and is associated to greater weight gain relative to sucrose in wistar rats. Nutrition and Metabolism, 14(1), 1-8.

Piper, P. W. (1999). Yeast superoxide dismutase mutants reveal a pro-oxidan action of weak organic acid food preservatives. Free Radical Biology and Medicine, 27(11-12), 1219-1227.

Qin, X. (2016). The possible link between artificial sweeteners such as saccharin and sucralose and inflammatory bowel disease deserves further study. Inflammatory Bowel Diseases, 22(6), e17.

Roberts, A. (2016). The safety and regulatory process for low calorie sweeteners in the United States. Physiology and Behavior, 164, 439-444.

Saurette, E. M., Groza, L. G., Blowes, D. W., \& Ptacek, C. J. (2017). Storage and preservation of artificial sweeteners in groundwater samples. Groundwater Monitoring and Remediation, 37(4), 71-81.

Shwide-Slavin, C., Swift, C., \& Ross, T. (2012). Nonnutritive sweeteners: Where are we today? Diabetes Spectrum, 25(2), 104-110.

Sørensen, F. W., \& Gregersen, M. (1999). Rapid lethal intoxication caused by the herbicide glyphosate-trimesium. Human and Experimental Toxicology, 18(12), 735-737.

Stella, J., \& Ryan, M. (2004). Glyphosate herbicide formulation: A potentially lethal ingestion. Emergency Medicine Australasia, 16(3), 235-239.

Su-Ah, J., Ahmed, M., \& Eun, J.-B. (2017). Physicochemical characteristics, textural properties, and sensory attributes of low-calorie cereal bar enhanced with different levels of saccharin during storage. Journal of Food Processing and Preservation, 42(2), e13486.

Suez, J., Korem, T., Zeevi, D., Zilberman-Schapira, G., Thaiss, C. A., Maza, O. Israeli, D., Zmora, N., Gilad, S., Weinberger, A., Kuperman, Y., Harmelin, A., Kolodkin-Gal, I., Shapiro, H., Halpern, Z., Segal, E., \& Elinav, E. (2014). Artificial sweeteners induce glucose intolerance by altering the gut microbiota. Nature, 514(7521), 181-186.

Snider, D. M., Roy, J. W., Robertson, W. D., Garda, D. I., \& Spoelstra, J. (2017). Concentrations of artificial sweeteners and their ratios with nutrients in septic system wastewater. Groundwater Monitoring and Remediation, 37(3), 94-102.

Sclafani, A., \& Ackroff, K. (2017). Flavor preferences conditioned by nutritive and non-nutritive sweeteners in mice. Physiology and Behavior, 173, 188-199.

Stanner, S. (2010). The science of low-calorie sweeteners - separating fact from fiction. Nutrition Bulletin, 35(4), 357-362.

Vasconcelos, M. A., Orsolin, P. C., Silva-Oliveira, R. G., Nepomuceno, J. C., \& Spanó, M. A. (2017). Assessment of the carcinogenic potential of high intensesweeteners through the test for detection of epithelial tumor clones (warts) in Drosophila melanogaster. Food and Chemical Toxicology, 101, 1-7. 
Vymazal, J., \& Dvoř́ková Březinová, T. (2016). Removal of saccharin from municipal sewage: The first results from constructed wetlands. Chemical Engineering Journal, 306, 1067-1070.

Weihrauch, M. R., \& Diehl, V. (2004). Artificial sweeteners - do they bear a carcinogenic risk? Annals of Oncology, 15(10), 1460-1465.

Williams, G. M., Kroes, R., \& Munro, I. C. (2000). Safety evaluation and risk assessment of the herbicide roundup and its active ingredient, glyphosate, for humans. Regulatory Toxicology and Pharmacology, 31(2), 117-165.

Yadav, A., Kumar, A., Das, M., \& Tripathi, A. (2016). Sodium benzoate, a food preservative, affects the functional and activation status of splenocytes at non cytotoxic dose. Food and Chemical Toxicology, 88, 40-47.
Yu, Y., \& Zhou, Q.-X. (2005). Adsorption characteristics of pesticides methamidophos and glyphosate by two soils. Chemosphere, 58(6), 811-816.

Yamashita, H., Matsuhara, H., Miotani, S., Sako, Y., Matsui, T., Tanaka, H., \& Inagaki, N. (2017). Artificial sweeteners and mixture of food additives cause to break oral tolerance and induce food allergy in murine oral tolerance model for food allergy. Clinical and Experimental Allergy, 47(9), 1204-1213.

Yang, Y.-Y., Liu, W.-R., Liu, Y.-S., Zhao, J.-L., Zhang, Q.-Q., Zhang, M., Zhang, J-N., Jiand, Y-X., Zhang, L-J., \& Ying, G.-G. (2017). Suitability of pharmaceuticals and personal care products (PPCPs) and artificial sweeteners (ASs) as wastewater indicators in the Pearl River Delta, South China. Science of the Total Environment, 590-591, 611-619. 